\title{
Keikhlasan Survivor Bencana Tsunami dan Gempa Aceh
}

\author{
Fuad Nashori \\ Universitas Islam Indonesia
}

This article aims to elaborating the results of study on the consciousness of the survivors of the earthquake and tsunami disasters in Aceh. The study, using interview and observation methods, reveals that the survivors have some such consciousnesses as: spiritual conciousness; psychological readiness; self reliance to shoulder any life burden; God forgiveness seeking; life meaning seeking; positive thinking; regretting of the past; surrendering to God and seeking God help. The study also shows some factors affecting the consciousness of the sunvivors, such as: faiths, knowledges, experiences, and family supports.

\section{Keywords: Consciousness, disasters, survivors}

$D$ alam upaya mempertahankan eksistensinya, umat manusia melakukan relasi dengan Tuhan, sesamanya, dan juga dengan alam. Khusus yang berkaitan dengan sesama manusia dan alam, relasi yang dijalani manusia itu bisa bersifat positif dan bisa pula bersifat negatif (Nashori, 2003). Relasi positif dengan sesama diwujudkan dalam aktivitas perhatian, kepedulian, persahabatan, pemberian pertolongan, dan sejenisnya. Relasi yang positif dengan alam dilakukan dengan mengelola dan meles-tarikan alam semesta. Sementara relasi yang bersifat negatif dengan sesama manusia ditandai oleh adanya pengabaian, penipuan, pertengkaran, peperangan, agresivitas, diskriminasi, dan sebagainya. Relasi yang negatif dengan alam ditandaj oleh eksploitasi alam oleh manusia dan oleh bencana alam seperti tsunami, gempa, letusan gunung, longsor, dan banjir.

Ketika manusia berhadapan dengan realitas bahwa relasi yang dijalaninya bersama alam dan sesama manusia itu bersifat negatif, banyak penderitaan yang dialami manusia. Ketika berhadapan dengan kenyataan bahwa tanah dan keluarga yang dicintainya diterjang oleh tsunami dan gempa, seorang warga Aceh merasakan penderitaan batin. Boleh dikatakan bahwa ketika berbagai situasi itu bersifat tidak menyenangkan, orang merasakan rasa sedih dan hilangnya kegembiraan.

Sebuah pertanyaan muncul, apakah pasti bahwa seseorang yang berhadapan dengan situasi objektif yang tidak menyenangkan pasti merasakan penderitaan? Hidayat (2005) yang melakukan asesmen psikologis terhadap survivor bencana Aceh menandaskan bahwa ternyata orang-orang yang merasakan dampak bencana tsunami dan gempa yang paling berat (yang disebut berada di ring I) menunjukkan penerimaan atas situasi kondisi yang dialaminya. Keselamatan yang dimilikinya dipandangnya sebagai mukjizat dan kalau akhimya keluarganya serta harta 


\section{Keikhlasan Survivor Bencana Tsunami dan Gempa Aceh; Fuad Nashori}

bendanya hilang atau musnah, la memandangnya sebagal realitas yang harus diterimanya. Keadaan seperti mengharuskan semua yang dlcintal dan dlsayanginya tiada, hilang dan musnah. Dalam dlrinya tumbuh kemampuan untuk menerima hal yang secara objektif tldak menyenangkan. Dia memillkl apa yang dlsebut sebagal kelapangdadaan (Nashorl, 2004; 2005).

Kelapangdadaan adalah suatu kondlsl pslko-splritual yang ditandal oleh kemampuan menerima berbagal kenyataan yang tldak menyenangkan dengan tenang dan terkendali' (Nashori, 2004). Orang yang lapang dada memillki kekuatan dalam llwanya untuk bertahan dan tidak berputus asa manakala menghadapi berbagal situas! yang secara objektlf tidak menyenangkan, balk secara psikis dan menyakitkan secara fislk. Semakin tinggl kelapangdadaan seseorang semakln mampu la menerima realitas yang beragam, termasuk yang tldak menyenangkan (Nashori, 2002).

Sltuasl yang tldak menyenangkan dapat saja terjadl karena faktor alam dan blsa pula karena faktor soslal. Contoh faktor alam adalah bencana ban]ir, longsor, tsunaml dan gempa buml. Menjadl korban bencana tsunaml dan gempa sebagalmana yang dialaml warga Nanggroo Aceh Darussalam secara objektif tldak dlsukal. Dalam kenyataannya, sebaglan besar korban bencana tsunami dan gempa Aceh merasakan penderitaan fislk dan psikologls. Namun, sebaglan dari mereka tetap menunjukkan slkap tenang dan terkendall. Ketenangan, mereka menghayatl peristiwa yang terjadl secara hollstlk, yaltu suatu kejadlan dipersepsi memlllki keterkaltan dengan kejadlan laln, misalkan bahwa bencana terjadl pastllah memillkl hlkmah. Mereka Juga menunjukkan yang dapat mereka kontrol secara balk sehingga tldak menimbulkan kerugian bagl dirl sendiri maupun orang lain dan lingkungannya.

Berkenaan dengan adanya realitas bencana yang begitu dahsyat pada masyarakat Aceh pada akhir 2004, banyak tenomena kelapangdadaan yang ditunjukkan oleh para survivor (orang-orang yang survive setelah terkena bencana). Sebagalmana diberitakan oleh Jawa Pos (6 Januari 2005), tsunaml melontarkan tubuh Rizal Sahputra ke hamparan Samudra HIndla. Pemuda tersebut terkatung-katung dl laut yang seakan tak bertepi itu selama delapan hari. Tekadnya untuk selamat hanya ditautkan pada sebatang pohon bercabang tiga yang berhasil diralhnya. Rizal menyebut cabang pohon itu pertolongan dari Tuhan. Dla sangat bersyukur ketlka lambalan dengan rantlng pohon Itu dikapal Malaysla. Akhirnya dla tertolong.

Pertanyaan lanjutan yang dapat ditampilkan adalah adakah kelapangdadaan in! dimillkl para survivor bencana Aceh? Kalau ya, tema-tema kelapangdadaan apa saja yang muncul dalam diri mereka? Selan. jutnya, faktor apa yang mempengaruhinya?

\section{Dasar teorl}

Kelapangdadaan (al-basith, al-samhah) adalah suatu kondisi psiko-splritual yang ditandal'oleh kemampuan menerima berbagal kenyataan yang tidak menyenangkan dengan tenang dan terkendali (Nashorl, 2004). Kondlsi psiko-spiritual adalah keadaan yang berada dalam diri seseorang yang berkaitan dengan perasaan dan pemikirannya sebagal makhluk Allah 'Azza wa jalla. Kenyataan yang tldak menyonangkan adalah semua kondisi yang berada dl dalam dan dl luar dir yang secara objektif tidak dlsukai seseorang.

Ciri-clil Kelapangdadaan. Sekurangkurangnya terdapat tujuh cirl pribadl yang 
lapang dada (Nashori, 2004a). Pertama, kesadaran spiritual (spiritual awareness), yaitu kesadaran bahwa keadaan yang tidak menyenangkan merupakan ujjan dari Allah 'Azza wa jalla. Orang yang lapang dada adalah seseorang yang kokoh menghadapi berbagai kenyataan hidup dan memandang kenyataan hidup sebagai ujian. Kekokohan itu dapat dicapal bila seseorang dilatih atau diuji secara terus menerus oleh Allah 'Azza wa jalla. Hal ini sesuai dengan firman Allah: Apakah manusia itu mengira bahwa mereka dibiarkan (saja) mengatakan: "Kami telah beriman," sedang mereka tidak diuji lagi? (QS al-Ankabut, 29:2).

Kedua, kesiapan psikologls (psycho. logical preparatory), yaitu kesiapan untuk menerima stimulasi yang tidak menyenangkan. Setelah sadar bahwa orang yang kokoh atau yang hebat harus melewati banyak ujian, maka tumbuhlah dalam diri orang tersebut kesiapan untuk berhadapan dengan hal-hal yang tidak menyenangkan. Kesiapan ini merupakan respons atas kepastian datangnya ujian dari Allah 'Azza wa jalla. Allah berfirman: Kamu sungguhsungguh akan diuji terhadap hartamu dan dirimu. Dan (juga) kamu sungguh-sungguh akan mendengar dari orang-orang yang diberi kitab sebelum kamu dan dari orangorang yang mempersekutukan Allah, gangguan yang banyak yang menyakitkan hati. Jika kamu bersabar dan bertakwa,maka sesungguhnya yang demikian itu termasuk urusan yang patut diutamakan (QS All Imran, 3:186).

Ketiga, keyakinan akan kesanggupan diri menanggung beban, yaitu keyakinan bahwa kesulitan yang ditanggung tak akan melebihi kesanggupan dirinya untuk menerima beban itu. Apapun ujian yang bakal atau dijalani seseorang, pasti telah tersedia kemampuan psiko-spiritual dan atau kemampuan fisik dalam diri seșeorang untuk mampu menerima beban itu. Allah berfirman: Allah tidak membebani seseorang melainkan sesuai dengan kesanggupannya (QS al-Baqarah, 2:286).

Keempat, pertaubatan, yaitu melakukan pertaubatan atas dosanya kepada Tuhan. Orang yang lapang dada ini sadar salah satu yang menjadikan kesulitan adalah dosadosa yang dilakukan manusia. Kadang kesulitan, yang sesungguhnya merupakan ujian itu, akibat dari kesalahan manusia. Bila seseorang sadar hal itu merupakan kesalahannya, maka la akan meminta ampunan dari Allah. Aktivitas bertaubat akibat kesalahan ini dicontohkan oleh $\mathrm{Nabi}$ Dawud. Allah berfirman: Dan Daud mengetahui Kami mengujinya, maka ia meminta ampun kepada Tuhannya lalu menyungkur sujud dan bertaubat (QS Shaad, 38:24). Di ayat yang lain Allah berfirman: Dan sesungguhnya Kamitelah menguji Sulaiman dan Kami jadikan ia tergeletak di atas kursinya sebagai tubuh (yang lemah karena sakit), kemudian ia bertaubat. la berkata: "Ya Tuhanku, ampunilah aku dan anugerahkanlah kepadaku kerajaan yang tidak dimillki oleh seorang juapun sesudahku, sesunguhnya Engkaulah yang Maha Pemberi."(QS Shaad, 38: 34-35).

Kelima, pemaafan (forgiveness), yaitu kesiapan memberikan ampunan/maaf bagi orang lain. Keterbukaan diri untuk memberi maaf kepada orang lain adalah tanda utama yang dapat segera ditangkap orang lain. Setiap kali menerima stimulasi yang tidak menyenangkan, Nabi Muhammad selalu memiliki kesiapan untuk memberikan maaf atau pengampunan terhadap seseorang yang menyakitinya. Salah satu contohnya adalah saat Nabi Muhammad mencoba berdakwah terhadap masyarakat Thait. Orang-orang Thaif ternyata tidak menerima dakwah yang disampaikan Nabi, bahkan lebih dari itu mereka mengusir dan melempari Nabi. 
Akibatnya, Nabi Mu-hammad pulang dengan tubuh dalam keadaan berdarah. Melthat keadaan yang tidak manusiawi tersebut, seorang malaikat menawarkan diri untuk melakukan pemba-lasan atas perilaku yang diterima Nabi. Tetapi Nabi Muhammad ternyata sangat pemaaf. Nabi Muhammad memberi isyarat memaafkan mereka sambil berdoa semoga anak cucu mereka akan menjadi orang- orang yang taat kepada Allah dan Rasul-Nya.

Keenam, pencarian hikmah (seoking meaning), yaitu keyakinan akan adanya hikmah atau pelajaran di balik peristiwa. Orang yang sehat secara ruhani akan dapat mengambil pelajaran bahwa di balik kesulitan ada pelajaran atau hikmah yang dapat diambil. Sementara orang-orang yang yang tidak sehat (munafik) tidak dapat mengambil pelajaran. Allah berfirman: Dan tidakkah mereka (orang-orang munafik) memperhatikan bahwa mereka diuji sekali atau dua kall setiap tahun, kemudian mereka tidak juga bertaubat dan tidak pula mengambil pelajaran (QS at-Taubat, 9:126).

Ketujuh, berpikir positif tentang masa depan (positive thinking), yaitu keyakinan akan adanya perbaikan keadaan setelah berlangsungnya keadaan yang tidak menyenangkan. Keadaan yang tidak menyenangkan pasti akan berlalu dan akan datang keadaan yang menyenangkan, tentu saja melalui usaha. Allah bertirman: Karena sesungguhnya sesudah kesulitan itu ada kemudahan. Sesungguhnya sesudah kesulitan itu ada kemudahan (QS alInsyirah, 94:5-6).

\section{Faktor-faktor yang Mempengaruhi Kelapangdadaan}

Adapun beberapa hal yang mempengaruhi tinggi rendahnya kelapangdadaan seseorang, yaitu: a. Keimanan. Seseorang yang memiliki iman yang kokoh di dalam hatinya percaya akan adanya takdir (ketentuan), ketentuan baik dan ketentuan buruk, yang telah ditetapkan Allah 'Azza wa jalla. Kalau seseorang selalu menyadari bahwa Allah menetapkan takdir baik dan buruk, maka mereka cenderung bisa menerima ketentuan Allah 'Azza wa jalla. Seseorang yang selalu beribadah adalah seseorang yang cenderung mengukuhkan iman terhadap takdir Allah 'Azza wa jalla.

b. Dzikir. Dzikir sendiri, menurut Subandi (1997), menghasilkan adanya perasaan lapang atau perasaan los (terbebas dari beban yang menghimpit). Penelitian empiris yang dilakukan Nashori (2005) menunjukkan bahwa ada hubungan antara kualitas dzikir dengan kelapangdadaan. Semakin tinggi kualitas dzikir semakin tinggi kelapangdadaan.

c. Tingkat Penderitaan yang dialami. Berat ringannya penderitaan yang dialami ikut serta mempengaruhi kelapangdadaan. Penderitaan yang luar biasa berat cenderung diterima dengan lapang dada dibanding yang agak kurang berat. Contoh, para survivorbencana gempa dan tsunami Aceh (Hidayat, 2005). Mereka yang berada di daerah Ring I (yang terkena gempuran tsunami, paling berat menerima dampak dari tsunami), ternyata cenderung berpandangan bahwa derita yang mereka alami berasal dari Tuhan, dan mereka dapat menerimanya sekalipun mereka harus meninggal karenanya. Sementara itu, para survivoryang berada di Ring II (yang terkena terjangan tsunami) cenderung kurang bisa menerima kenyataan. Mereka menyesali mengapa mereka tidak bisa 
menolong istri, anak, atau orangtuanya.

d. Sumber penderitaan. Kalau sumber penderitaan itu karena ulah manusia, maka orang cenderung lebih sulit untuk berlapang dada. 'Sementara kalau seseorang itu memahami bahwa penderltaan yang mereka alami itu berasal dari Tuhan, maka mereka cenderung berlapang dada. Contohnya adalah orang-orang Aceh cenderung melihat bencana berasal darl Tuhan cenderung tidak banyak mengalami gangguan psikologis berat (seperti post traumatic stress disorder) akibat bencana. Penyebab gangguan psikologis berat pada orang Aceh terutama adalah peperangan antara Pemerintah Indonesia/Tentara Nasional Indonesia dan GAM (Gerakan Aceh Merdeka). Perang dianggap sobagai ulah manusla hal yang menyebabkan adanya penderltaan pada masyarakat Aceh.

e. Usia. Orang yang berusia memasuki lansia cenderung lebih dapat menerima penderitaan daripada orang yang lebih muda. Hal ini dikarenakan pengalaman mereka lebih banyak dibanding dengan orang-orang yang berusia leblh muda.

f. Lingkungan. Seseorang yang berada dalam lingkungan yang terlatih untuk berhadapan dengan suasana yang tidak menyenangkan leblh besar kelapangdadaannya dibanding mereka yang berada dalam lingkungan yang tidak melatih mereka untuk menerima beragam situasi. Pondok pesantren adalah lingkungan yang memblasakan diri seseorang untuk hidup prlhatin.

g. Pengalaman penderitaan sebolumnya. Berbagal pengalaman penderitaan, semisal kehilangan orang-orang 'penting dalam kehidupannya akan menjadikan seseorang leblh kokoh ketika menghadapl keadaan yang tidak menyenangkan. Anak-anak yang merasakan kesedihan karena hilangnya teman main mereka atau nenek dan kakek mereka akan menjadi lebih kokoh menghadapi situasi yang tidak menyenangkan dibandingkan anak yang tidak pernah merasakan sitauasl yang sama.

Pertanyaan Penelitian

Pertanyaan-pertanyaan penelitian yang diajukan dalam penelitian inl adalah:

1. Tema kelapangdadaan yang menonjo! pada survivor bencana Aceh?

2. Bagaimana proses pencapalan kelapangdadaan survivor Aceh?

\section{Metode Penelitian}

Subjek Penelitian. Subjek penelitian ini adalah enam orang $A c e h$ yang menjadi survivor peristiwa gempa bumi dan tsunaml Aceh yang berlangsung pada 26 Desember 2004. Subjek penelitian tinggal dl Banda Aceh dan Yogyakarta.

Fokus Penelitian. Fokus penelitian Ini adalah tema-tema kelapangdadaan dan proses terbentuknya kelapangdadaan survivor bencana tsunami dan gempa dl Aceh.

Metode Pengambllan Data. Penelltian ini menggunakan metode kualltatlf. Dalam penelitlan ini data yang berlsl kelapangdadaan survivor Aceh diungkap dengan menggunakan wawancara secara mendalam (In depth interview). Wawancara adalah percakapan dengan maksud tertentu. Percakapan ini dilakukan oleh dua pihak, yaitu powawancara dan yang diwawancarai

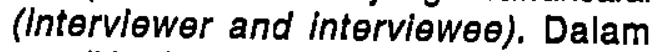
penelitlan ini akan digunakan jenis wawancara baku terbuka (Moleong, 1994). Maksudnya, wawancara dilakukan dengan menggunakan seperangkat pertanyaan baku. Urutan pertanyaan, kata-katanya, dan 
cara penyailiannya pun sama untuk setiap responden.

Diungkapkan oleh Guba dan Lincoln (dalam Moleong, 1994) bahwa wawancara jenis di atas mestinya dilakukan secara terstruktur. Dalam hal ini pewawancara menetapkan sendiri masalah dan pertanyaan-pertanyaan yang akan diajukan. Untuk itu pertanyaan-pertanyaan disusun ketat. Sampel atau responden ditanyai dengan pertanyaan yang sama dan hal ini penting sekali. Semua subjek mempunyal kesempatan yang sama untuk menjawab pertanyaan yang diajukan.

Objektivitas dan keabsahan data penelitian dilakukan dengan melihat reliabilitas dan validitas data yang diacu. Dikatakan oleh Moleong (1994), validitas ditentukan oleh kredibilitas temuan dan interpretasinya dengan mengupayakan temuan dan penafsiran yang dilakukan sesuai dengan kondisi yang senyatanya dan disetujui oleh subjek penelitian.

Untuk keperluan di atas, dalam penelitian ini dilakukan pendalaman data dengan cara mengambil data secara intens. Bila diperlukan akan dilakukan wawancara secara berulang, terutama untuk mengungkap hal-hal yang konsisten dalam upaya memenuhi kriteria reliabilitas data.

Teknik Analisis Data. Adapun teknikteknik analisis data dilakukan sebagai berikut. Pertama, setelah dilakukan wawancara, dilakukan analisis domain untuk mengetahui domain yang tercakup dalam kelapangdadaan survivor tsunami dan gempa Aceh. Kedua, wawancara terstruktur (tertulis) dari domain tertentu. Di sini peneliti akan memfokuskan diri pada domain yang telah ditentukan berkaitan dengan kelapangdadaan survivor. Ketiga, bila dipandang perlu akan dilakukan wawancara lanjutan untukmengungkap berbagai persoalan yang perlu dikaji lebih lanjut. Keempat, mengontraskan antar elemen dalam domain yang diperoleh dari wawancara kontras. Hal yang keempat ini dilakukan bila terdapat pernyataan yang saling bertentangan.

\section{Hasil Penelitian dan Pembahasan}

Untuk mengungkap kelapangdadaan survivor bencana gempa dan tsunami Aceh, kami melakukan wawancara dengan enam responden. Agar wawancara dapat berlangsung baik, maka kami membangun rapport terlebih dahulu. Sebelum wawancara dilakukan pewawancara meminta izin terlebih dahulu kepada responden. Selaion wawancara, dilakukan pula observasi. Wawancara dan observasi berlangsung antara 15 Jull hingga 30 September 2006. Nama-nama responden adalah TA, LS, DA, $P L, D M$, dan $A D$. Catatan: Lebih lanjut ungkapkan di sini identitas subjek (nama, umur, tinggal, pekerjaan, pendidikan terakhir, karakteristik, dan seterusnya).

Berikut ini akan diungkapkan tematema kelapangdadaan dan faktor-faktor yang mempengaruhi kelapangdadaan responden penelitian berdasarkan wawancara yang dilakukan terhadap enam responden.

\section{Tema-tema Keikhlasan}

a. Kesadaran Spiritual (spiritual awareness)

Kesadaran spiritual (spiritual awareness), yaitu kesadaran bahwa keadaan yang tidak menyenangkan merupakan ujian dari Allah 'Azza wa jalla.

i. Tema pertama adalah sadar bahwa Allah 'azza wa jalla maha berkehendak "Orang-orang membangun rumah dan kota selama berpuluh-puluh tahun, tapi hanya dalam tempo lima menit semua hilang. Bagi saya, kalau Tuhan meng- 
hendaki, maka dalam hitungan menit bahkan mungkin detik semua yang merasa kita miliki dapat diambil-Nya. Ya, kapan saja kita bisa dipanggilNya." (TA) .

"Sesuatu yang terjadi tu lebih mungkin orang tua Putra memberipemahaman kuasa Allah memang harus begitu dah gak bisa bilang apa-apa kama yang membuat/menciptakan tu bisa berhak siapa-siapa yang mau mati bisa, memang hak dia (Allah)...kalo berkeluh kesah kenapa gini-gitu gak boleh tu, kita pasrah saja, semua yang terjadi pasti ada baiknya. Semua dah ditetapkan.... Kita jalani aja...." (LS) "Seperti yang adek alami sekarang ini mungkin ini udah ketentuan Allah" (AD)

ii. Tema kedua adalah memahami bahwa melalui tsunami Alloh menunjukkan kebesaran-Nya "gimana ya kak...Adek gak berfikir ke arah situ...gak berfikir kekuasaan Allah tu gimana, jujur aja adek gak terfikir kesitu, tapi kalau sekarang kejadian tsunamilah yang menunjukkan kekuasaan Allah yang paling besar" (AD)

iii. Tema ketiga adalah mudah mengingat Allah dalam kehidupan sehari-hari "Kalau dalam kehidupan sehari-hari, misalnya kalau berbuat sesuatu yang kurang baik atau kesalahan langsung teringat pada Allah" (AD)

iv. Tema keempat adalah memandang tsunami adalah peringatan dari Allah "Tsunami itu peringatan. Sebelum tsunami itu masyarakat Aceh itu agak gimana gitu. Maksudnya? Banyak yang menyimpang akhlaknya. (TA)

v. Tema kelima adalah kesadaran bahwa Allah bermaksud baik dengan cobaan yang diberikan-Nya melalui tsunami "Allah itu baik, mungkin yang tahun lalu itu cobaan untuk kita supaya kita menyadari perilaku yang kita lakukan pada masa lalu, sekarang kita harus memperbaikinya Allah memberi cobaan ini agar kita tetap sabar" (PL)

\section{Kesiapan psikologis (psychologi- cal preparatory)}

Kesiapan psikologis (psychological preparatory), yaitu kesiapan untuk menerima stimulasi yang tidak menyenangkan.

i. Tema keenam adalah memiliki pengetahuan tentang gejala-gejala tsunami, namun ada yang berpikir bahwa tidak mungkin air laut naik ke darat

"Saya pernah mendengar informasi kalau ada gempa yang berayun tandanya ada tsunami. Saya ketahui itu dari orang-orang sebelumnya. Lalu saya menghadap ke arah selatan, ke arah laut. Mulai panik gitu." (TA)

"Dari sisi airnya, datangnya air bergemuruh yang gak pernah kita lihat sama sekali, mana mungkin air laut naek ke darat, ni yang pertama kali dan itu yang paling berkesan, hitam lagi airnya kental.." (PL)

ii. Tema ketujuh adalah lebih memahami isi al-Qur'an tentang fenomena alam "Setelah tsunamitu banyak lah hikmah yang didapat...mungkin kayak bintang yang mengellingi bumi ini...kita kayak ditengah-tengah seperti diawasi dan dilindungi" (LS)

iii. Tema kedelapan adalah meningkat kesadaran bahwa bisa saja sewaktuwaktu manusia dipanggil oleh Tuhan "Dulu sebelum tsunami saya palingpaling hanya rajin shalat maghrib. Shalat yang lain masih sering bolongbolong. Sejak peristiwa tsunami itu saya semakin menyadari bahwa kapan saja kita dapat dipanggil-Nya. Kini saya shalat lima waktu penuh."(TA) 
iv. Tema kesembilan adalah tahu dari alQur'an bahwa bencana alam yang sangat dahsyat dapat kapan saja mengenai manusia

"Isial-Quran itu banyak kak ya...salah satunya terjadinya bencana alam, kan ada juga dalam al-Quran" (PL)

v. Tema kesepuluh adalah kemampuan manusia mempersiapkan diri tidak optimal

"Kita ini hidup mati gak tau kapan... apapun yang disruh diperiapkan mungkin belum siap sama kita, kapanpun bisa dipanggil...hal tsunami itulah...hal yang gak diduga-duga, barusan kita ketawa, barusan beberapa menit lalu kita ketawa ma dia beberapa menit kemudian kita liat mayat dia.." (LS)

Dari penjelasan di atas dapat diketahui bahwa sebagian responden menyadari bahwa peristiwa yang luar biasa seperti tsunami suatu saat bisa saja terjadi. Mereka merasa tetap kuat sekalipun perasaan mereka berat menghadapi semua itu. Menurut Atkinson dkk (2004), pengetahuan tentang kemungkinan hal-hal yang buruk tentang sesuatu dapat mengurangi stres yang terjadi. Responden yang tahu bahwa tsunami adalah kejadian yang mungkin berlangsung dalam kehidupan mereka akan lebih siap secara psikologis.

Keyakinan akan kesanggupan diri menanggung beban

Keyakinan akan kesanggupan diri menanggung beban, yaitu keyakinan bahwa kesulitan yang ditanggung tak akan melebihi kesanggupan dininya untukmenerima beban itu.

i. Tema kesebelas adalah keyakinan akan kesanggupan diri menghadapi keadaan yang menyedihkan. "ya..merasakan kasih sayang Nya dengan diberikan kita cobaan ya.. karna Allah masih sayang sama kami maka diksih cobaan, apakah kita sanggup menjalaninya.. alhamdulillah sampe sekarang masih sanggup walaupun masih ada sisa-sisa kesedihan karna kejadian kemaren.."(DM)

ii. Tema kedua belas adalah merasa tidak lemah sekalipun sangat kehilangan keluarga.

"yang pasti kalo untuk mengubah sesuatu berat kak, misalnya pada waktu tsunami dikki meronta-ronta mana adik dikki, mana bapak dikki gitu kan, dikki gak mungkin di depan mamak, kalo dikki lemah pasti ya hancur semua kami, pada waktu tu gimana membuat perasaan ini, menyembunyikannya walaupun menipu di depan mamak, dikki harus membohongi diri dikki sendiri, terkadang....kadang-kadang mamak tanya di mana bapak dikki. Kenapa ibu masih tanya? karena mayatnya gak ketemu, kenapa gak cari, mungkin kalo dapat pun bisa stress atau apa...ada hikmahnya juga gak ketemu tapi dalam batin dikki berontak juga harus ketemu...tapi kalo dikki piker kalo seandainya ketemu dikki liat juga psikologis mamak pasti dia gak nerima...." (DA)

Apapun ujian yang bakal atau dijalani seseorang, pasti telah tersedia kemampuan psiko-spiritual dan atau kemampuan fisik dalam diri seseorang untuk mampu menerima beban itu. Allah berfirman: Allah tidak membebani seseorang melainkan sesuai dengan kesanggupannya (QS alBaqarah, 2:286).

\section{Pertaubatan}

Pertaubatan, yaitu melakukan pertaubatan atas dosanya kepada Tuhan.

i. Tema ketigabelas adalah insaf atas kesalahan mengganggu orang lain 
"Kejadian tsunami ini betul-betul emang kak, pokoknya insaflah kak, kalo mungkin sering ganggu orang gak ada manfaatnya lagi gitu kan" (DA)

ii. Tema keempat belas adalah sadar akan kesalahan diri kepada orangtua"sama juga, malah lebih parah dulu daripada sekarang, sama ayah juga, sekarang sadar karna gak ada lagi.... (ayah meninggal)" (PL)

"kurang baik mungkin ya..karna adek pun ada masalah sedikit dengan keluarga bukan masalah orang tua karna pun keluarga bisa dikatakan keluarga yang kurang utuh, ada mungkin, ada sifat atau akhlak adek yang gak baik dengan orang tua" (AD) "dikki pribadi, kalo dikki sayang sama orang tua, dulu orang tua dikki punya kateringan di rumah, dikki Bantu, kalo sempat kadang-kadang pagi...waktu kejadian tsunami, dikki ingat kali waktu tu ibu lagimasak trus ayah sakit minta diurut badan, dikki urut, kata mamak urut dulu bapak abistu Bantu mamak. Trus dikki urut bapak, dikki Bantu mamak, trus mamak bilang kayaknya bapak dikki tu macam (seperti) orang mau meninggal seperti tu....mungkin ikut nenek, alah....dikki diam aja, apa yang bisa digoreng gorenglah kan, kalo cuci piring, cuci piring...ya pada waktu bais kejadian tsunami kan dikki ingat lagi, nyesal juga hilang bapak dikki kek gitu kalo gak kan masih ada, gak lah mak itu kan dah takdir" (W1.DA.Brs.349-361)

iii. Tema kelima belas adalah sadar bahwa dulu suka mengganggu guru, tapi sekarang tidak lagi

"Dulu badung sih, waktu SMA namanya juga SMA kawan rame, sering cabut, rame di belakang, biasanya sering ganggu guru-guru $B P$, tapi begitu dah kuliah gak lagi sih bahkan dikki pendiam kak jarang ikut-ikut kegiatan di kampus, kalo dulu waktu masih SMP kalo hari sabtu dan minggu pasti gak da di rumah, pasti ada kegiatan, contohnya apa aja...tapi sekarang lebih banyak waktu di rumah" (DA)

iv. Tema keenam belas adalah merasa menyesal kurang optimum berbuat baik untuk orang-orang dekat yang dipanggil-Nya

"Ya saya sangat menyesal dulu saya kurang optimal berbuat baik untuk paman-paman dan bibi saya. Mereka telah dipanggil-Nya. Nyesel saya mengapa dulu gak kunjungi mereka. Saya menyesal juga orang sebaik mereka diambil-Nya juga. Padahal mereka orang-orang baik." (TA)

v. Tema ketujuh belas adalah memohon ampun atas kesahan yang diperbuat "ya dengan memohon ampun atas kesalahan yang diperbuat" (AD)

vi. Tema kedelapan belas adalah mengkompensasi kesalahan dengan perbuatan positif.

"ya...salah satu wujudnya salah satunya putra gak mau mencemarkan nama baik orang tua, oke lah prilaku kita emang buruk tapi gak mau orang mengkait-kaitkan sama orang tua, kalo orang tua gak ada lagi ya dengan doa kita kasih kan...bantu sebisa kita ajalah...baik itu kerjaan disuruh apa...sebisa kita mampu aja..." (LS)

Orang yang lapang dada ini sadar salah satu yang menjadikan kesulitan adalah dosa-dosa yang dilakukan manusia. Kadang kesulitan, yang sesungguhnya merupakan ujian itu, akibat dari kesalahan manusia. Bila seseorang sadar hal itu merupakan kesalahannya, maka ia akan meminta ampunan dari Allah atas kesalahan yang diperbuatnya. 


\section{Pemaafan}

i. Tema kesembilan belas adalah tidak mudah marah kepada orang lain sekalipun orang lain marah "alhamdulillah baik, gak pernah kami marah-marahan" (DM)

"kalo dulu, karena dikki masih muda, kadang-kadang jiwa mudanya masih nampak, kadang-kdang perilaku sama teman juga terbawa tapi coba mengurangi hal-hal seperti tu kayak tutur kata, seperti kemaren ke bawa emosional, waktu antar ibu ke rumah sakit kan minggu kan gak ada yang buka dokter praktek'kan, dikki waktu tu bawa kereta (motor), kata mamak ngapainliat $k e$ belakang ntar terbalik, jeh (tho) orang mau nengok (lihat) kok, kata dikki (merasa kesal)....abistu nyesal juga ngapain maahin mamak dah sakit gitu kan....sedih juga, akhirnya mamak yang gak enak sendiri...diam aja dikki, abistu mamak yang ajak bicara" (DA)

\section{Pencarian hikmah (seeking mean- ing)}

Pencarian hikmah (seeking meaning), yaitu keyakinan akan adanya hikmah atau pelajaran di balik peristiwa.

i. Tema kedua puluh adalah kesadaran bahwa Allah memberi kesempatan untuk beramal lebih banyak

"Dulu badung sih, waktu SMA namanya juga SMA kawan rame, sering cabut, rame di belakang, biasanya sering ganggu guru-guru BP, tapi begitu dah kuliah gak lagi sih bahkan Dikki pendiam kak jarang ikut-ikut kegiatan di kampus, kalo dulu waktu masih SMP kalo hari sabtu dan minggu pasti gak da di rumah, pasti ada kegiatan, contohnya apa aja...tapi sekarang lebih banyak waktu di rumah" (DA)

"Allah masih memberikan kesempatan hidup untuk adek untuk perbanyak amal" (AD)

"Dengan hilangnya keluarga kita ya, kita percaya kalo umur tu gak lama jadi selama sisa-sisa hidup kita banyakin amal lah ya, mendekatkan diri sama Allah" (DM)

ii. Tema kedua puluh satu adalah menjadi pribadi yang lebih sabar, tawakkal, tabah.

"putri lebih apa ya....(bingung), lebih... lebih...bertawakkal pada Allah, lebih berdikir pada Allah" ( $P L)$

"adek hadapi dengan sabar ya kak" (AD)

"putri berusaha untuk sabar, tabah, pokoknya menghadapi itu, putri kemballin pada Allah aja lah...." (PL) “....kadang-kadang mamak tanya dimana bapak dikki. Kenapa ibu masih tanya? karena mayatnya gak ketemu, kenapa gak cari, mungkin kalo dapat pun bisa stress atau apa...ada hikmahnya juga gak ketemu tapi dalam batin dikki berontak juga harus ketemu...tapi kalo dikki piker kalo seandainya ketemu dikki liat juga psikologis mamak pasti dia gak nerima...." (DA)

Para survivor tsunami dan gempaAceh dapat mengambil pelajaran bahwa di balik kesulitan ada pelajaran atau hikmah yang dapat diambil. Sementara orang-orang yang yang tidak sehat (munafik) tidak dapat mengambil pelajaran. Allah berfirman: Dan tidakkah mereka (orang-orang munafik) memperhatikan bahwa mereka diuji sekali atau dua kali setiap tahun, kemudian mereka tidak juga bertaubat dan tidak pula mengambil pelajaran (QS at-Taubat, 9:126). 


\section{Berpikir positif tentang masa depan' (positive thinking)}

Berpikir positif tentang masa depan (positive thinking), yaitu keyakinan akan adanya perbaikan keadaan setelah berlangsungnya keadaan yang tidak menyenangkan.

i. Tema kedua puluh tiga adalah ke depan harus bisa berbakti kepada orangtua "Saya kini kuliah D3 di FE-UST. Saya ingin lakukan yang terbaik. Cepat lulus juga. Hingga takjadi beban orangtua. Saya juga sadar bahwa orangtua hidupnya berat. Saya tidak mau minta yang macam-macam. Walau saya ingin punya motor, tapi sudahlah gak apa gak ada motor. Saya tidak ingin membebani orangtua." (TA)

"Kadang kalo makan ingat, sakit hati juga, kenapa sih terpecah belah keluarga hilang semua, emang kesannya palak, sepi itu kan... kenapa bisa terjadi ehm... kalo menurut dikki gak juga, orang tua dikki yang satu ni lah yang harus kek mana dikki harus bisa berbakti sama dia kan, itu yang paling penting, mungkin itu harta yang paling penting" (DA)

ii. Tema kedua puluh empat adalah Keinginan memperbaiki moral masyarakat Aceh

"Saya ingin mengubah perilaku moral orang Aceh. Saya belum tahu apa yang dapat saya perbuat, tapi saya ingin mengubah mereka. Apa yang semestinya diubah? Saya lihat banyak peristiwa kriminal, banyak judi, juga pencurian. Saya ingin kasih pengarahan-pengarahan agar mereka juga mendekatkan diri kepada Allah." (TA) Keadaan yang tidak menyenangkan pasti akan berlalu dan akan datang keadaan yang menyenangkan, tentu saja melalui usaha. Allah berfirman: Karena sesungguhnya sesudah kesulitan itu ada kemudahan. Sesungguhnya sesudah kesulitan itu ada kemudahan (QS al-Insyirah, 94:5$6)$.

Dari tujuh aspek yang diduga muncul, ternyata hanya enam aspek yang muncul. Adapun aspek yang tidak muncul adalah kepasrahan kepada Tuhan $(\mathrm{H})$.

Kepasrahan dan Pertolongan Tuhan

i. Tema kedua puluh lima adalah perasaan sudah tak berdaya lagi, kemudian pasrah

"Rasanya tenaga saya sudah habis. Saya merasa tidak kuat lagi. Saya berpikir mungkin saya tidak selamat." (TA)

"Sore hari ternyata terjadi tsunami susulan, tapi tidak sebesar yang pagi hari. Kami tinggal di masjid. Orangtua saya bilang untuk tetap bertahan di masjid saja. Kalau akhimya terjadi apaapa kami pasrah." (TA)

ii. Tema kedua puluh enam adalah perasaan pasrah terhadap keadaan orang-orang yang dicintai

"Padahal saya ingin lagi turun untuk mengetahui keadaan orangtua dan adik saya. Saya sangat stres memikirkan orangtua dan adik saya yang masih smp. Saya ingin menemui mereka tapi tidak diperkenankan oleh orang-orang. Akhirnya saya pasrah." (TA)

ii. Tema kedua puluh dua adalah merasa ditolong atau diberi selamat oleh Tuhan "Cuma kejadian tsunami tu aja karna masih diberi kesempatan selamat" (LS)

"Tapi tiba-tiba ada mobil sampah yang mengajak saya untuk naik. Tuhan menolong saya dengan mobil itu. Di atas sampah itu saya itu saya lihat 
sejumlah orangtua yang terluka. Sambil naik mobil itu saya, orangorang yang terbawa arus air tsunami." (TA)

\section{Faktor-faktor yang mempengaruhi kelapangdadaan}

Berikut ini akan diungkapkan faktorfaktor yang mempengaruhi kelapangdadaan.

a. Faktor keimanan

Keyakinan kepada takdir Allah akan membantu seseorang untuk memiliki kelapangdadaan saat menghadapi bencana.

"Mungkin terutama amal kita, ketika ajal menjemput yang harus dipersiapkan mal kita, abistu amal dan ibadah kita, minta maaf pada keluarga, orang terdekat, orang di sekitar, apabila berbuat salah dan semoga mereka mau memaafkan agar lebih tenang kesana" (AD)

"lebih bertawakkal pada Allah, lebih mengingat Allah, butuh dukungan, motivasi supaya lebih tenang, lebih baik, ataupun bantuan-bantuan fisik" (AD)

b. Faktor pengalaman

Salah satu pengalaman yang penting mempersiapkan masyarakat Aceh menghadapi bencana tsunami adalah perang GAM. Walaupun skalanya berbeda; bencana perang saudara yang berlangsung lama mempengaruhi para responden.

"Pengalaman stres menghadapi pertikaian GAM dan Tentara Nasional membuat orang kuat menghapi situasi yang tidak menentu." (TA)

c. Faktor dukungan keluarga dan yang lain

Dukungan yang diberikan keluarga dan orang lain akan memperkokoh kelapangdadaan responden.

"ya...keluarga karna masih ada keluarga yang utuh, masih ada ayah, adik-adik rame, biarpun ada kesedihan, kesenangan, itu hal biasa dalam keluarga, tapi tu sangat berkesan punya keluarga yang sangat kita sayangi, kita butuhkan." (AD)

\section{Pembahasan}

Kelapangdadaan pernah digambarkan oleh Gymnastiar (Nashori, 2004) sebagai danau yang luas. Kalau seseorang memiliki danau yang luas dalam jiwanya, maka mereka menganggap tidak berarti adanya kotoran yang masuk ke danau tersebut. Maksudnya, bila seseorang memiliki wadah psiko-spiritual yang luas atau memiliki kelapangdadaan, maka ia tidak akan serta merta menjadi marah besar, putus asa, atau stres, manakala menghadapi musibah atau peristiwa-peristiwa yang tidak menyenangkan. Gambaran yang kongkrit adalah sebagaimana kelapangdadaan $\mathrm{Nabi}$ Muhammad saat menerima penghinaan dari orang-orang kafir. Muhammad begitu tenang dan terkendali menghadapi mereka. Semua ini menggambarkan luasnya wadah psikospiritual seseorang. Namun, kalau wadah psiko-spiritual seseorang sempit, misalnya yang diandaikan Gymnastiar (Nashori, 2004) sesempit gelas, maka kotoran atau polusi yang mengenai mereka akan mereka terkena pengaruh buruk atas kehadiran benda-benda tersebut. Dari penelitian terungkap secara jelas bahwa responden memiliki kelapangdadaan yang menonjol pada diri responden

Adanya kelapangdadaan, menurut Gymnastiar (Nashori, 2004), atau ternyata dipengaruhi oleh keimanan, aktivitas ibadah dan perilaku sehari-hari seseorang, serta informasi yang dimiliki seseorang. Hal ini didukung hasil penelitian bahwa keimanan dan ibadah merupakan faktor yang mempengaruhi kelapangdaan. Ini mendukung hasil penelitian Nashori (2005) di mana 
seseorang yang banyak berdzikir akan terkena imbasnya, yaitu kelapangdadaan.

Sebagaimana ditemukan dalam penelitian, orang-orang Aceh yang menjadi responden memiliki kelapangdadaan yang luar biasa. Kelapangdadaan yang mereka miliki bersumber dari religiusitas yang menonjol yang ada dalam diri mereka. Religiusitas ini dapat diketahui dari pemahaman mereka yang baik akan isi ajaran al-Qur'an. Isi ajaran al-Qur'an yang khusus berkaitan dengan bencana dan tsunami pun mereka pahami dengan baik. Hal ini sebagaimana terungkap dari pernyataan subjek ini.

"Isial-Quran itu banyak kakya...salah satunya terjadinya bencana alam, kan ada juga dalam al-Quran" ( $P L)$

Pemahaman akan isi al-Qur'an ditambah dengan aktivitas religius lain yang dilakukan masyarakat Aceh adalah adalah sesuatu yang dapat menyadarkan diri individu bahwa Allah adalah penentu segala sesuatu. Bila kesadaran spiritual ini menguat dalam diri individu, maka individu akan berubah menjadi manusia yang baru, yaitu sosok manusia yang memiliki keluasan batin atau kelapangdadaan. Transformasi individu ini bersifat relatif permanen. Artinya, kalau seseorang memiliki religiusitas secara berkualitas, maka itu akan berperan banyak dalam hal membentuk wadah psiko-spiritual yang luas.

Selain itu, catatan khusus lainnya adalah subjek penelitian ini, yaitu mahasiswa, umumnya memiliki pengetahuan yang memadai tentang masalah tsunami, sebelum adanya tsunami 26 Desember 2004. Mereka memiliki informasi tentang berbagai macam hal, termasuk tanda-tanda bencana. Hal ini menjadjkan mereka dapat memahami bencana, baik dari kitab suci (alQur'an) maupun yang berasal dari literatur masa kini.
"Saya pernah mendengar informasi kalau ada gempa yang berayun tandanya ada tsunami. Saya ketahui itu dariorang-orang sebelumnya. Lalu saya menghadap $k e$ arah selatan, $k e$ arah laut. Mulai panik gitu." (TA)

"Isial-Quran itu banyak kakya...salah satunya terjadinya bencana alam, kan ada juga dalam al-Quran"(PL)

Faktor lain yang tak kalah pentingnya dalam mempengaruhi kelapangdadaan adalah pengelaman pendahuluan yang dimiliki subjek. Salah satu pengalaman yang penting mempersiapkan masyarakat Aceh menghadapi bencana tsunami adalah perang GAM. Walaupun skalanya berbeda, bencana perang saudara yang berlangsung lama mempengaruhi para responden. Pengalaman berada dalam situasi tertekan di zaman GAM menjadikan wargaAceh lebih lapang dalam menghadapi tsunami. Hal ini sebagaimana diungkapkan oleh salah seorang subjek.

"Pengalaman stres menghadapi pertikaian GAM dan Tentara Nasional membuat orang kuat menghapi situasi yang tidak menentu." (TA)

Terakhir, dukungan sosial yang diberikan keluarga dan orang lain akan memperkokoh kelapangdadaan responden. Hal ini sebagaimana diungkapkan oleh subjek.

"ya...keluarga karna masih ada keluarga yang utuh, masih ada ayah, adikadik rame, biarpun ada kesedihan, kesenangan, itu hal biasa dalam keluarga, tapi tu sangat berkesan punya keluarga yang sangat kita sayangi, kita butuhkan." (AD)

Penelitian yang penulis lakukan pada warga Bantul yang menjadi survivor bencana gempa menunjukkan hal yang sama (Nashori, 2007). Bahkan pada warga Bantul, kebersamaan, gotong royong, atau suasana 
guyub terasa sangat kental. Beberapa responden menuturkan hal berikut ini:

Ya ...jadinya dengan tetangga-tetangga itu kita lebih merasakan sependeritaan, sama-sama ngerasain, saling gotong royong. Jadi waktu itu kita pernah tinggal dua haridibase camp... Sama tetangga lebih akrab. Lebih bisa merasakan kebersamaan gitu tho ... Ternyata kalo tetangga itu saudara yang paling deket. (ENP)

Di sini makanan selalu ada dari tetangga nih, bahkan sampai tiga piring.. ya banyak yang kasih sama saya, meskipun saya gak meminta, bahkan berlebihan untuk makannya. Alhamdulillah ya kalau hubungan tetangga itu... semua baik sama saja (Slamet, 40 tahun)

Suasana guyub ini tidak menjadi isu yang menonjol pada survivor Aceh. Ini tidak berarti tidak ada keguyuban pada masyarakat Aceh. Keguyuban atau kegotongroyongan ada namun bukan menjadi kerangka utama dalam budaya Aceh, sementara pada budaya jawa keguyuban atau kolektivitas menjadi isu yang penting.

\section{Daftar Pustaka}

Al-Mundziri, Zaki Al-Din 'Abd Al-Azhim (peny.), 2002, Ringkasan Shahih Muslim. Terjemahan: S. Djamaluddin \& Mochtar Zoemi. Bandung: Penerbit Mizan.

Ash-Shiddiqie, Hasby, 1992, Pedoman Dzikir dan Doa. Jakarta: Penerbit Bulan Bintang.

Az-Zabidi, Imam Zainuddin Ahmad bin AbdulLathif (ed.), 2002, Ringkasan Shahih Al-Bukhari. Terjemahan: Cecep Syamsul Hari \& Tholib Anis. Bandung: Penerbit Mizan.
Bastaman, Hanna Djumhana, 2005, Integrasi Psikologi dengan Islam: Menuju Psikologi Islami. Yogyakarta: Yayasan Insan Kamil dan Pustaka Pelajar.

Cahyadi, Ahmad, 2004. Hubungan antara Intensitas Dzikir dengan Kecerdasan Emosi. Skripsi. Tidak Diterbitkan. Yogyakarta: Fakultas Psikologi UII.

Hamid, Abdul Fattah Rashid, 1996, Pengenalan Diri dan Dambaan Spiritual. Jakarta: Pustaka Firdaus.

Hidayat, Rahmat, 2005, Peta Problem Psikologis Para Survivor Bencana Gempa dan TsunamiAceh. Makalah. Dipresentasikan dalam Diskusi Memahami Lebih Mendalam Bencana Aceh. Hasil Kerjasama PP Asosiasi Psikologi Islami dan Panitia Psikologi UII Peduli Aceh, Yogyakarta, 18 Januari 2004.

Ilham, MuhammadArifin \& Debby Nasution, 2004, Hikmah Dzikir Berjamaah. Jakarta: Penerbit Republika.

Nashori, H. Fuad, 2002; Agenda Psikologi Islami. Yogyakarta: Pustaka Pelajar.

Nashori, H. Fuad, 2003, Kitab Suci Sebagai Sumber Pengembangan Psikologi Islami. Makalah ini disampaikan dalam Kegiatan IImiah, Kongres Asosiasi Psikologi Islami (API) I, Surakarta, 10-12 Oktober 2003.

Nashori, H. Fuad, 2004, Menjadi Pribadi yang Lapang Dada. Buletin AlIslamiyyah, Nomor 18, Th. XII, Februari 2004. 
Nashori, H. Fuad, 2004, Manajemen Qalbu: Bagaimana Menyikapi Penderitaan Hidup? Bahan Kuliah Blok Kesehatan Jiwa Fakultas Kedokteran UII Yogya.

Nashori, H. Fuad, 2005, Kiat-kiat Penulis Muslim Kreatif. Yogyakarta: Quranic - Media Pustaka.

Nashori, H. Fuad, 2007, Kelapangdadaan Survivor Bencana Gempa di Yogya.
Hasil Penelitian. Jakarta: Dikti Depdiknas.

Pennebaker, James W, 2002, Ketika Diam Bukan Emas. Bandung: Mizan.

Poerwadarminto, W.J.S, 1989, Kamus Bahasa Indonesia. Jakarta; Departemen Pendidikan dan Kebudayaan Rl.

Subandi, 1997, Tema-tema Pengalaman Spiritual Pengamal Dzikir. Jurnal Psikologika, II, (3), 7-18. 